\title{
"Code of ethics for SMEs: substantiating the necessity and willingness to implement in Ukraine"
}

\author{
Larysa Antoniuk (D) https://orcid.org/0000-0003-1389-4720 \\ R http://www.researcherid.com/rid/J-7149-2015 \\ Igor Britchenko iD https://orcid.org/0000-0002-9196-8740 \\ R http://www.researcherid.com/rid/H-9866-2018 \\ AUTHORS \\ Yevheniia Polishchuk iD https://orcid.org/0000-0002-6133-910X \\ R http://www.researcherid.com/rid/J-5444-2018 \\ Nataliia Rudyk iD https://orcid.org/0000-0002-4367-0392 \\ Yuliia Sybirianska iD https://orcid.org/0000-0003-4075-3560 \\ R http://www.researcherid.com/rid//-9157-2018 \\ Pavel Machashchik (D https://orcid.org/0000-0002-4234-9572
}

Larysa Antoniuk, Igor Britchenko, Yevheniia Polishchuk, Nataliia Rudyk, Yuliia Sybirianska and Pavel Machashchik (2018). Code of ethics for SMEs:

ARTICLE INFO substantiating the necessity and willingness to implement in Ukraine. Problems and Perspectives in Management, 16(3), 150-162.

doi:10.21511/ppm.16(3).2018.12

DOI

http://dx.doi.org/10.21511/ppm.16(3).2018.12

RELEASED ON

Monday, 30 July 2018

RECEIVED ON

Tuesday, 20 March 2018

ACCEPTED ON

Friday, 04 May 2018

(c))EY

LICENSE

This work is licensed under a Creative Commons Attribution 4.0 International License

JOURNAL

ISSN PRINT

ISSN ONLINE

PUBLISHER

FOUNDER
"Problems and Perspectives in Management"

$1727-7051$

$1810-5467$

LLC "Consulting Publishing Company "Business Perspectives"

LLC "Consulting Publishing Company "Business Perspectives"
NUMBER OF REFERENCES

23
NUMBER OF FIGURES

7
NUMBER OF TABLES

1

(C) The author(s) 2022. This publication is an open access article. 


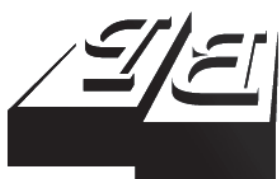

BUSINESS PERSPECTIVES

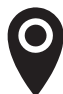

LLC "CPC "Business Perspectives" Hryhorii Skovoroda lane, 10, Sumy, 40022, Ukraine

www.businessperspectives.org

Received on: $20^{\text {th }}$ of March, 2018 Accepted on: $4^{\text {th }}$ of May, 2018

(c) Larysa Antoniuk, Igor Britchenko, Yevheniia Polishchuk, Nataliia Rudyk, Yuliia Sybirianska, Pavel Machashchik, 2018

Larysa Antoniuk, Vice-rector, D.Sc. (Economics), Professor, Kyiv Nationa Economic University named after Vadym Hetman, Ukraine.

Igor Britchenko, Doctor Habil., Professor, State Higher Vocationa School Memorial of Prof. Stanislaw Tarnowski, Poland.

Yevheniia Polishchuk, D.Sc. (Economics), Professor, Kyiv National Economic University named after Vadym Hetman, Ukraine.

Nataliia Rudyk, Ph.D. in Economics, Associate professor, Kyiv National Economic University named after Vadym Hetman, Ukraine.

Yuliia Sybirianska, Ph.D. in Economics, Associate professor, Kyiv National Economic University named after Vadym Hetman, Ukraine.

Pavel Machashchik, PhD, Rector at State Higher Vocational School Memorial of Prof. Stanislaw Tarnowski, Poland.

\section{(c) (i)}

This is an Open Access article, distributed under the terms of the Creative Commons Attribution 4.0 International license, which permits unrestricted re-use, distribution, and reproduction in any medium, provided the original work is properly cited.
Larysa Antoniuk (Ukraine), Igor Britchenko (Poland), Yevheniia Polishchuk (Ukraine), Nataliia Rudyk (Ukraine), Yuliia Sybirianska (Ukraine), Pavel Machashchik (Poland)

\section{CODE OF ETHICS FOR SMES: SUBSTANTIATING THE NECESSITY AND WILLINGNESS TO IMPLEMENT IN UKRAINE}

\begin{abstract}
The article substantiates the necessity of development and implementation of ethical rules of doing business into the business practices of small and medium enterprises. Particular attention is paid to business entities in Ukraine as a country with one of the highest levels of shadow economy. The two-level structure of SMEs' Code of Ethics designed by the author is being presented, which is based on the following key concepts: transparency of business entities activity, partnership integrity, environmental and social responsibility, which are interrelated and reflected in the individual modules of the Code.

The article presents the results of approbation of the author's Code of Ethics for SMEs. The approbation is based on a personal and interactive questionnaire about the readiness of Ukrainian SMEs representatives to introduce ethical norms into their activities. The authors determined that Ukrainian SMEs are not well-informed about possible positive effects from following norms and rules in business, in particular, in terms of improving the business climate in the country, increasing the investment attractiveness of the economy as a whole and economic entities in particular, simplifying the access to financial and credit instruments.
\end{abstract}

The survey and questionnaire of Ukrainian SMEs confirmed the need for the development and implementation of the business Code of Ethics norms, as well as potential demand for it. The respondents recognize the importance of certain international ethical rules in conducting business, which may contribute to attracting investment in Ukraine; however, this is not the only factor affecting the investment attractiveness of domestic business. It is substantiated that the business climate improvement is a complex issue, and the Code of Ethics, in this context, creates the opportunities of guiding and encouraging participants to the active influence on the business environment: to declare zero tolerance to corruption and to form and to maintain clear position in interactions with the public authorities.

\section{Keywords}

small and medium enterprises, code of ethics, business ethics, corporate, ecological, and social responsibility of business

\section{JEL Classification M13, M14, M21}

\section{INTRODUCTION}

Small and medium-sized businesses are the most numerous category of business entities of any country and, at the same time, the most mobile, efficient and innovative part of it. The micro, small and medium-sized enterprises sector is one of the largest not only in Ukraine, but also in other developed and developing countries.Thus, more than 95\% of the OECD legal entities are included in this category and they provide around two thirds of private employment (OECD, 2005). The SMEs play an important role in economic development through creating employment opportunities; mobilization of domestic savings; poverty reduction; more proportional distribution of income; promotion of regional development; creating an environment in which large companies operate, etc. Taking into consideration that small and medium-sized businesses are the most numerous category of business 
entities of any country and, at the same time, the most mobile, efficient and innovative part of it, the development and introduction of new approaches of doing business, shifting their emphasis from a purely commercial purpose to the needs of following principles of corporate, social and environmental responsibility are important. Special attention should be paid to finding the ways of improving the interactions between both the government, large and small businesses and citizens of the country. Therefore, the transparency of relations and changes in the mentality of doing business by business entities, the transition to a partner relationship between a specific SME representative and its key stakeholders, the efforts to implement their activities, taking into account the social, environmental and economic priorities and needs of the country, become of high priority.

In this context, entrepreneurial ethics, which should cover not only corporate, but also social and environmental responsibility of economic and financial actors, is of particular importance. However, the mechanism for the implementation of ethical norms in the business environment remains unclear, more subjective, individual, and practically not applied at the level of small and microenterprises. SMEs are not well aware of the possible positive effects of complying with the provisions of the Code of Business Ethics, in particular, on improving the business climate in the country, increasing the investment attractiveness of the entire country's economy and individual SME entities in particular and, as a result, facilitating access to financial and lending instruments.

That is why the purpose of this publication is to justify the need to develop and outline the benefits and risks of introducing a code of conduct for business of small and medium entrepreneurs in general and in Ukraine as a country with one of the highest levels of shadow economy in particular, as well as assessment of the readiness of Ukrainian SMEs to the introduction of ethical norms in their activities. The object of research is the relations that arise between the subjects of small and medium business and their key stakeholders in the process of economic activity. At the same time, it is not pretended to develop an innovative Code of Ethics for doing business, but there is a need to demonstrate the feasibility and the possibility of adapting the codes of corporate ethics existing in the world practice to the specifics of the functioning of small and medium-sized enterprises, taking into consideration their investment and innovation orientation and socio-economic responsibility.

\section{LITERATURE REVIEW}

Works of Schwarz are devoted to problems of changing mentality and behavior in business through their formalization (2001). The researcher advises that the Code of Ethics should be used as a tool of positive influence on the ethical behavior of employees, management, partners, etc. Later, Schwartz (2005) argues that their presence is a decisive factor in choosing between the "right decision" from the employer's ethical point of view and the "right decision" from the employee's ethical point of view, which can be a tool of manipulation.

Practical studies of McKinney, Emerson, and Neubert (2010) serve for deeper understanding of the problem, in which it is confirmed that the existence of a written Code of Ethics reduces the probability of unethical and risky situations for subjects of financial relations. The authors emphasize that the implementation of the Code of Business Ethics on the micro level affects the level of admissibility of unethical behavior of entities, which further influences the state (especially on compliance with legislation, in particular, environmental), competitors (unacceptable competitive advantages), shareholders (income forecasting), hired workers (fair wage level). It should be noted that it is possible for enterprises as subjects of the economy to outline the inverse relationship between the size of the company and the subjectivity of the made decisions: in big companies, where important decision-making procedures involve attracting more people, it is more likely that the decision will be objective and rational at the expense of the broader overall qualification, more experience, and, often, carrying out preliminary calculations.

Paunov (2016) believes that SMEs are more inclined to be engaged in corruption schemes than 
representatives of big business. In particular, the author focuses on obtaining corrupt practices of patents and certificates for innovative inventions and processes. However, such an affirmation needs to be reinforced by the results of interviews and surveys. Xu and Yano (2017) in their research prove that corrupt measures have a reverse effect on the propensity of the country and its business entities to innovate, which, in turn, is the main factor of economic growth and is responsible for the accumulation of innovative potential. Certainly, the corruption that occurs in the area of SMEs activity violates ethical standards and increases the likelihood of their deviant behavior, which affects the potential for their development.

Sharma and Dudeja (2013) note that the ethics of the SMEs decisions is affected by personal factors, values and psychology of the manager. In due time, Longenecker, Moore, Petty, Palich, and McKinney (2016) noted that the ethics of doing business depends on the size of a business entity. According to statistics, SMEs are the main employer, which provides more than half of employment and, thus, a significant share in the overall creation of economic value. However, big business obviously has more practical and financial tools to implement corporate and social responsibility practices that should be part of the current Code of Ethics. At the same time, the issue of social acceptance of good faith for both small and medium or large enterprises arises, as there are both advantages and disadvantages of applying corporate, social and environmental responsibility practices as an incentive to receive full or additional funding for innovation.

Grunig and Hunt (1984), Pieczka and L'Etang (2001), Wiley (2000) argue that in international practice compliance with the provisions of the Code is an infrastructure necessity for any relationship. Kim Soo-Yeon and Ki Eyun-Jung (2014) indicate that the professional codes of business form the basic and specific values of the activity, revealing their importance to the society.

One cannot ignore the only normative approach to the need of formulating the provisions of the Code of Ethics for SMEs. Thus, Tilley (2015) in his work convinced that attempts to introduce the Ehical Code are only deontological tools. In fact, compliance with the Code of Business Ethics, in our opinion, is not only a collection of rules, but also a tool to increase their profits in the medium and long term.

Selçuk et al. (2016) have proved that the religious beliefs of the SMEs representatives in Turkey generally have a positive impact on the tradition of conducting their business. Although they do not consider it necessary to apply special codes in their activities, however, in their opinion, in general, religious norms can replace such codes. Of course, on the domestic market, such an approach is possible, because, in our view, the external economic environment will require other approaches beyond the limits of religious ethics.

In this direction, Schwartz (2005) also conducted a study in which he rightly interprets the Code of Business Ethics as a normative guideline document in which codified moral values should remain relevant regardless of differences in culture, religion, time, and circumstances.

At the same time, there are opposite views on the feasibility of developing and implementing the Code of Ethics for SMEs. Thus, Vyakarnam, Bailey, Myers and Burnett (1997) consider such an event to be unrealistic. At the same time, they do not exclude the possibility of a certain list of general reference points and recommendations for conducting ethical business, which will be of a formal nature and will function at the level of SMEs solely on a voluntary basis. The authors violate the significant ethical controversy related to the specifics of SMEs. They are organized into ethical dilemmas: conflict of interest, personal interests, stakeholders and transparency.

In previous studies concerning the prospects of SMEs development in conditions of the 4th industrial revolution (Antoniuk et al., 2017), we also paid the attention to the substantiation of the necessity of government support to SMEs and, in particular, to encourage the development and implementation of codes of conduct of business on the basis of corporate and social responsibility in their work. Their application will have a positive impact on the image of SMEs, improve their relationships with investors, financial institutions, consumers and other stakeholders. 
Despite the considerable efforts of scientists in this direction, there is still a need to study the appropriateness and readiness for the implementation of the Code of Ethics of small and medium-sized enterprises based on the corporate and social responsibility of enterprises in Ukraine, as well as providing recommendations for the use of its provisions by financing innovations.

\section{METHODS}

The elaboration of the Code of Ethics for small and medium-sized enterprises based on the social and corporate responsibility provided for a series of successive stages. First, some relevant literary sources have been studied that have proven the need for changes in ethical rules of the enterprises conduct, as well as regulatory documents that address issues of ethics in business conduct. Secondly, foreign experience of implementing such codes in the practice of business structures was analyzed. Thirdly, the provisions of the author's Code of Ethics for small and medium-sized enetrprises on the basis of social and corporate responsibility have been developed, which was made public on the website of the Information Platform on Support for SMEs Innovation (sme-sci.com). All interested persons and survey participants were able to express their opinion on the usefulness and meaningful content of the Code of Ethics placed on this Information Internet Platform in an online mode. In addition, in order to publicize and encourage practical application, the author's draft of the Code of Ethics for SMEs was sent to a number of organizations, in particular EU-UA Civil Society Platform, Public Organization "Economists Club", the Center for "Corporate Social Responsibility Development", The Union of Enterepreneurs of Small, MiddleSized and Privatized Enterprises, as well to Verkhovna Rada Committee on Industrial Policy and Entrepreneurship of Ukraine. Today, the structure of the Code of Ethics for the conduct of SMEs takes into consideration the recommendations and comments of these initiative organizations.

Fourthly, in order to determine the respondents' opinion about need for business in the Code of Ethics, the following types of questionnaires were conducted: formal interactive (direct delivery of the questionnaires of the participants (represent- atives of SMEs) to electronic mailboxes (received through their own contacts, appeals to business associations), or information with a request for an online application form that was created using Google Forms); formal personalized (structured individual interviews of SMEs representatives (participants in thematic business forums, conferences, symposiums, seminars held from June to December 2017) with the same, well-prepared list of issues (see Figure 2). The results of the questionnaire and the pilot survey are presented below.

Table 1. The list of questions of marketing research on the theme "Necessity of the Code of Ethics implementation for the Management of Small and Medium-Sized Enterprises"

Source: Systematized by the authors based on the conducted research and questionnaires.

Questions

1. Do you agree with the need to implement a single Code of Ethics for doing business?

- Yes

- No

- Some rules but not the Code

- Don't see any sense

2. Do you have ethical rules of conduct and conduct business at your enterprise, such as the Code of Conduct of Corporate Ethics?

- No

- Yes (please note in field "other")

- No, but we plan to elaborate

- To follow the paras of agreements

- Rules of employees conduct

- Under elaboration

- Decency

3. In your opinion, can the Code of Ethics Conduct of SMEs change the mentality of the subjects of domestic business?

- Yes, if everybody follows it

- No

- Yes

- No, this is just another bureaucratic document

- Changes through education, not codification

4. In your opinion, does the image of the company affect the interest of domestic and foreign investors?

- Yes, depending on the company's image, the image of the country is formed

- Image - a relative thing: today, it is good, and tomorrow - it is spoiled, so it doesn't affect

- No. The interest of foreign investor is influenced exclusively by political and economic factors

- There is no trust yet (for investing)

5. What are the reasons for distrust of foreign investors to domestic business (you can choose several options):

- Corruption

- Instability of legislative framework

- Complexity of legislation framework

- Unstable economic situation

- Monopolization of business spheres

- Insufficient ROI compared to other countries

- Lack of strategic partnership

- Military activity in the East

- Significant risk of investments losses

- Language barriers

- Lack of systemacity of the business itself 
Table 1 (cont.). The list of questions of marketing research on the theme "Necessity of the Code of Ethics implementation for the Management of Small and Medium-Sized Enterprises"

\section{Questions}

6. In your opinion, the most important principle for foreign investors may be compliance with the company's responsibility:

- Of all three above mentioned

- Corporate

- Social

- Financial

- For the performance of own obligations (contractual)

7. Choose/complete the key, in your opinion, structural modules of the Code of Ethics for the conduct of SMEs (you can choose several options):

- Guarantees of decent attitude of hired workers

- Main principles of cooperation with counterparties

- Norms of corporate conduct

- Attitutude to environment and natural resources use

- Principles of interbranch and national partnership

- Principles of interaction with financial institutions

- Interaction with civil institutions

- Complex of measures

- See question 1

- Transparency of financial statements

8. In your opinion, the maximum result in the regulation of relations enshrined in the Code can be achieved (you can choose several options):

- through the creation of the information platform for mutual monitoring

- through its legalization (acquiring a status of a law)

- through the establishment of separate organization concerning monitoring of its provisions

- See question 1

- Teambuilding

9. What, from your point of view, can be an alternative to the Code in the regulation of financial relations:

1) between the state and business:

- Legislation

- Compliance to legislation

- Tax Code of Ukraine

- No corruption

- Mutual trust

2) between financial institutions (banks, ICl, others) and business:

- Demand/proposition

- Law enforcement agencies, courts

- Int. agreements

- Legislation

- Trust

3) between representatives of business:

- Legislation

- Nothing, this is market

- Custom

- Mutual interest

- Agreements cannot stipulate all terms and conditions

- Trust

10. What are your suggestions for the content of the Code of Ethics for small and medium-sized businesses?

- Monetary flow inside and outside the country

- They exist

- Don't support

- None
In the course of the survey, 2100 questionnaires were sent. From them, 757 fully completed questionnaires were received (including 373 from enterprises that identified themselves as medium-sized, and 384 from small enterprises). Sample reliability was calculated using the sample size calculator for confidence interval 5\% and confidence level $95 \%$.

The results of the survey confirmed the need to develop the Code of Ethics for doing business and made it possible to improve the structure and content of this document.

Finally, the author's development has been finalized and made publicly available on the website of the Information Support Internet Platform for SMEs (sme-sci.com), which is accessible to all interested parties.

\section{RESULTS}

In recent years, Ukraine has considerably worsened its international competitiveness. This is confirmed by the experts of the World Economic Forum. Although Ukraine slightly improved its position compared with the previous period, and in the 2017-2018 report, it is on the 81st out of the 137 studied countries. According the methodology of World Economic Forum, Ukraine belongs to the countries that provide their competitive advantages, being at the stage of efficiency. According to the sub-index "Institutions", Ukraine ranked 118th, while its position is the worst among the CIS countries (see Figure 1).

According to the rating, the following indicators were affected by the results obtained for this sub-index: protection of shareholders' interests (129th place), independence of the court (129th place), property rights (128th place); protection of intellectual property rights (119th place). The low overall performance appraisal of the government has dropped Ukraine to the top ten countries in the world ranking for this group of indicators. So, according to the indicator of ethical behavior of companies in two years Ukraine lost 26 positions (102nd place among 137 countries of the world) in comparison with the previous period. One of the problems that causes low competitiveness is unethical behavior of companies (102nd place among 137 countries). 


\section{Ukraine \\ Hungary \\ Bulgaria \\ Slovac Republic \\ Romania \\ Latvia \\ Poland \\ Slovenia \\ Lithuania \\ Czech Republic \\ Estonia}

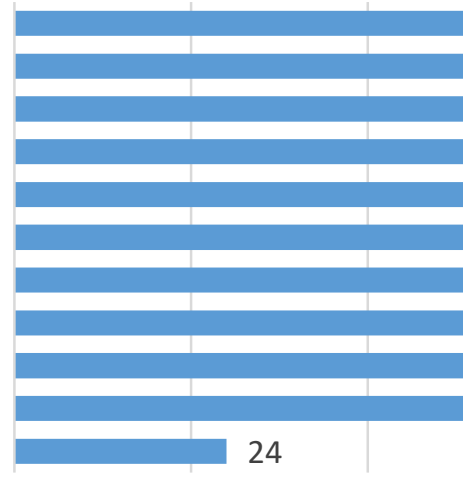

0

20

40

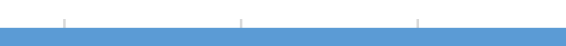

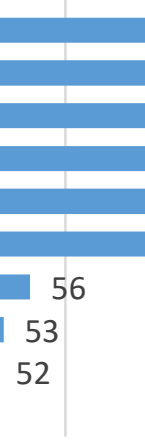

118

101

98

93

86

82

72

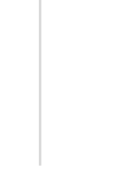

80

100

120

Figure 1. Place of Ukraine under the sub-index "Institutions"

Source: Compiled by the authors.

\section{THE GUARANTEES OF THE DECENT ATTITUDE TO THE HIRED WORKERS: \\ - a guarantee of a favorable and safe working environment; \\ - support for cultural diversity as opposed to discrimination and prosecution; \\ - regulation of the process of hiring and employment; \\ - motivation to increase intellectual capital through training and development.}

\section{NORMS OF CORPORATE BEHAVIOR:}

- protection of the company's property;

- rules for using telecommunication systems and ensuring the confidentiality of information;

- requirements for corporate gifts;

- encouraging a healthy lifestyle. COUNTERPARTIES:

- the principle of responsibility and principle of conscientiousness;

- principle of impartiality when choosing partners;

- quality control when working with partners;

- intellectual Property Rights Guarantee;

- satisfying customer inquiries and complaints;

- supporting competition and counteracting

market; monopolization;

- special requirements for contracts and contacts.

\section{MAIN PRINCIPLES OF WORK WITH}

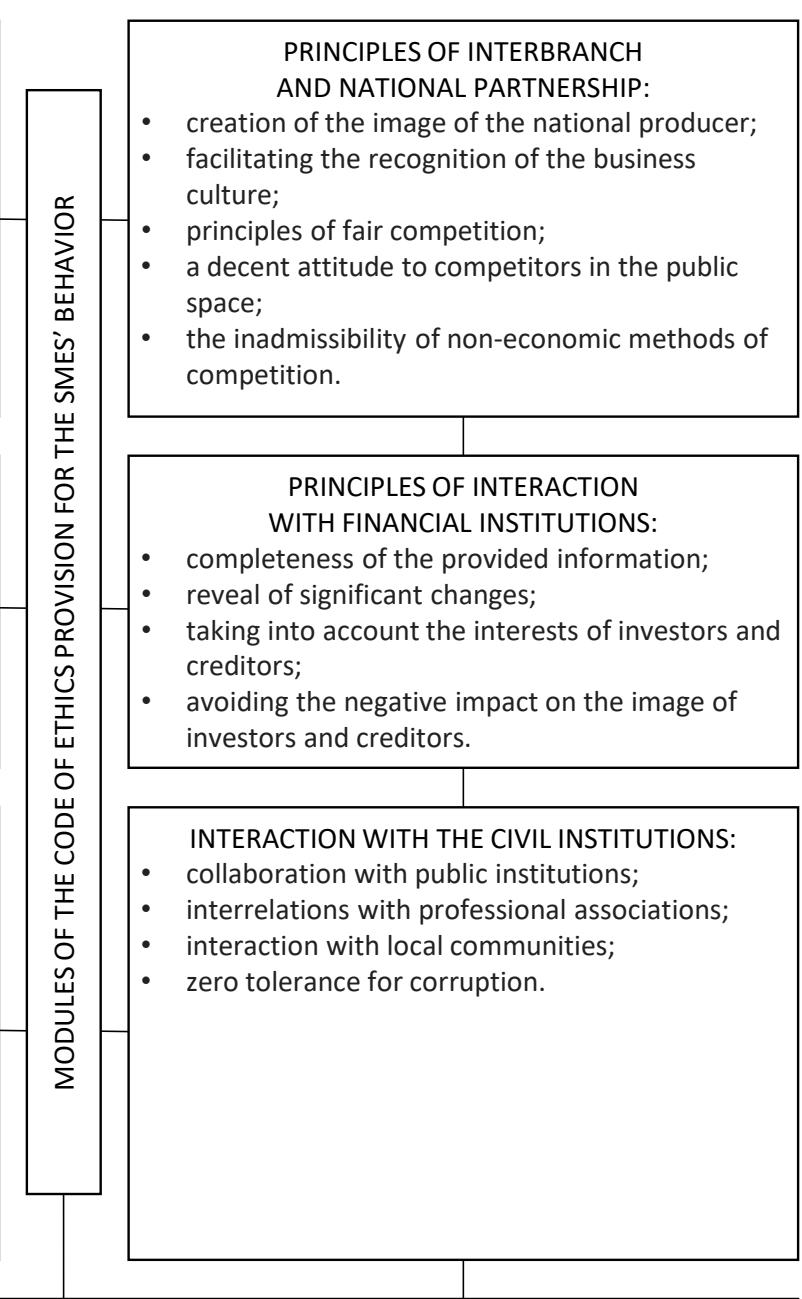

THE ENVIRONMENT AND USING OF NATURAL RESOURSES:

- compliance with environmental policy;

- optimality of strategies and tools according to environmentally friendly goals;

- environmental orientation in relations with contractors.

Figure 2. The main modules of the Code of Ethics provision for the SMEs' behavior 
This means that there is a sharp demand on ordering relationships between business representatives and other stakeholders. Such ordering can be realized by implementating that formal unformal and unformal rules. They can be formed in Code of Ethics for SMEs.

According to the groups of interaction of the SMEs with the subjects of economic and financial relations, a two-tier structure of the provisions of the Code of Ethics for the conduct of SMEs is presented, as shown in Figure 2. The structure is based on such key accents as honesty (transparency of activities) of business entities, partnership integrity, environmental and social responsibility, reflected in individual modules of the Code and interrelated. In addition to this, the key goals were the sustainable development goals that outline and confirm priorities and aspirations in the global economic and financial spheres for the period up to 2030. They should serve as a benchmark for Ukraine, and in particular the Ukrainian SMEs, in seeking their preferences in the world community and restoring trust and interest from potential investors.

The approbation of the draft provisions of the Code of Ethics for the SMEs' conduct was carried out within the framework of the marketing research by the survey method of the event participants, as mentioned above. The marketing research "The Need for Implementation of the Code of Ethics for the Management of Small and Medium-Sized Enterprises" was conducted within the framework of participation in the International Forum
"Innovation Market", held on November 21-24, 2017, as well as social networking tools (Facebook, Telegram) and focus groups within the framework of a scientific project and with the support of the Ministry of Education and Science. The object of the study was the ethical component of business activity, the subject of the study was the potential of its unification as the Code of Ethics for the management of small and medium-sized enterprises. The information of the marketing research is relevant and available for analysis. The respondents were able to pass a survey on the list of questions, the structural indicators of the results of responses to which are presented in Figures 3-7.

Consequently, within the framework of the survey, a questionnaire was conducted among the representatives of 757 SMEs. Each of the respondents was asked 10 open and closed-ended questions about their assessment of the value and status of the ethical component of doing business, the prospects for implementing the Code and the vision of its individual components. Among the respondents, $80 \%$ responded positively to questions about the need to implement certain rules of the business ethics or a single Code of Business Ethics, which determines the relevance of the research direction and the demand for the results of the work on the Code development (Figure 3).

At the same time, only $30 \%$ of the respondents have introduced Codes of Corporate Ethics or certain rules of the employees' conduct. Another $23 \%$ of those polled said that such documents are planned or are already under development. The

Source: Calculated by the authors on the basis of the conducted research.

1. Do you agree with the need to implement a single Code of Ethics for doing business?

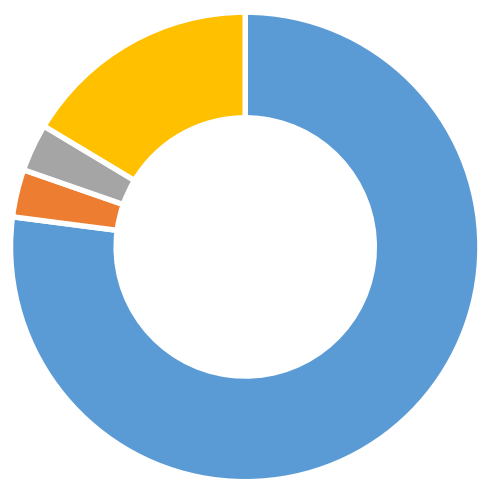

- Yes (77\%)

- Some rules but not the Code $(3 \%)$

- Don't see any sense (3\%)

No $(16 \%)$

Figure 3. Structural indicators of answers to questions that determine the urgency of the research 
3. In your opinion, can the Code of Conduct Ethics of SMEs change the mentality of the subjects of domestic business?

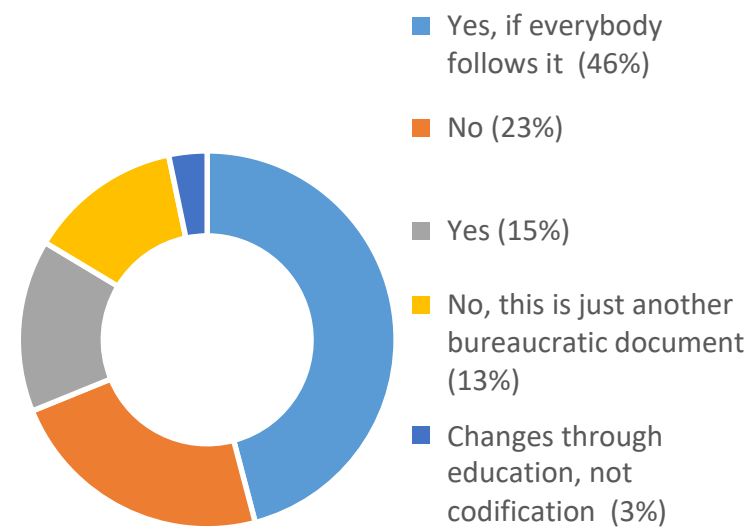

4. In your opinion, does the image of the company affect the interest of domestic and foreign investors?

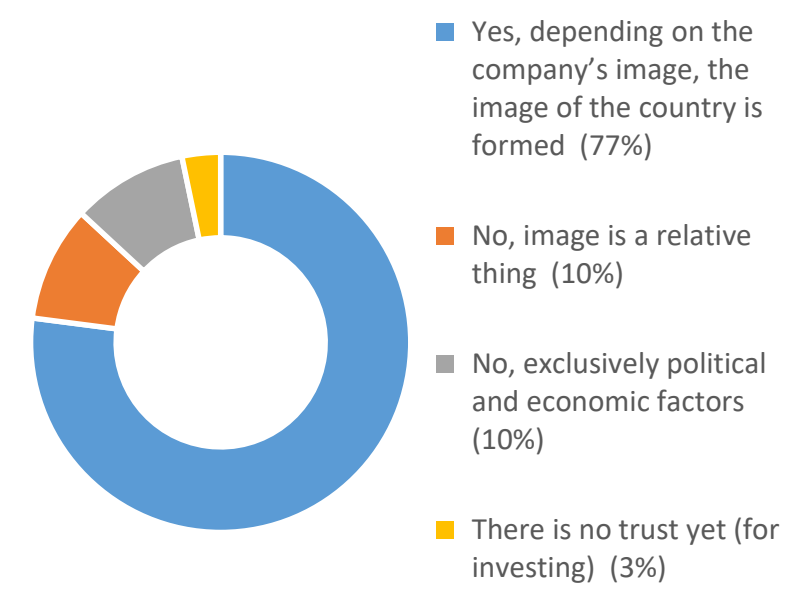

Figure 4. Structural indicators of answers to questions that determine the possibility of using the results, applying qualitative research methods

predominance of positive responses to the question of the need for the Code can be interpreted as a potential demand for a single document for the SMEs sector, which avoids the cost of resources for the development of individual provisions and documents.

Based on the objectives of implementing the Code, it was important for the respondents to receive feedback on the expected potential of the Code, in particular, the impact on the mentality of SMEs and their image among the investors (Figure 4).

$61 \%$ of the respondents agree with the possibility of changing the mentality of subjects of domestic business. However, only a quarter of them unconditionally agree with the potential impact of the Code. The rest defined the need for the instruments to enforce it.

Among the priority methods, the tools of mutual supervision and monitoring prevailed (48\% of the respondents). And only $31 \%$ consider the Code's status of the law to be effective.

The respondents also agree with the importance for foreign investors of having ethical norms of doing business (Figure 5): 77\% of the respondents agree that the image of the company is shaping the image of the country. However, the key factors of investment attractiveness and trust in domestic business were the complexity and instability of the legislative base (37\% of the respondents), corruption (25\%), instability of the economic situation (13\%), monopolization of business (11\%), and low profitability, lack of opportunities for strategic partnership, military activity in the East, risks of investment losses, language barriers, unsystematic business $(<10 \%$ of respondents). That is, the key obstacle to attracting investors to business is infrastructure issues, and then - economic attractiveness. In this aspect, the Code creates the opportunity to direct and encourage the participants to influence actively on the environment: to recognize zero tolerance for corruption, to formulate and to maintain a clear position on interaction with the authorities.

The respondents' vision of the structure of the code is as follows: $70 \%$ of the respondents determine the equivalence of corporate, social and environmental responsibility; $15 \%$ of those consider the dominant corporate responsibility, $10 \%$ - the social one. Therefore, hypothetically, it can be argued that today, the conduct theory has a significant impact on the country's market, and a significant positive impact on the image of Ukrainian business can be carried out by ele- 
Source: Calculated by the authors based on the conducted research.

5. What are the reasons for distrust of foreign investors to domestic business (you can choose several options):

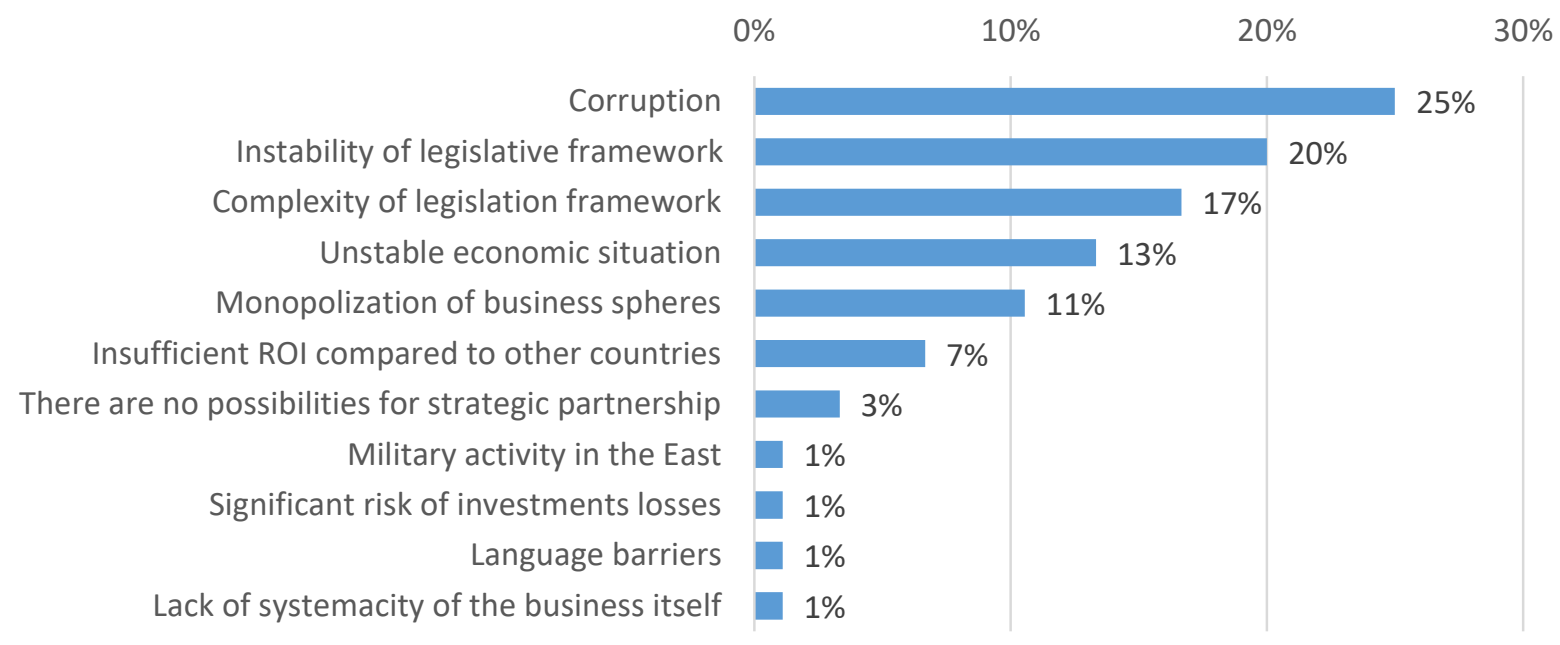

6. In your opinion, the most important principle for foreign investors may be complance with the company's responsibility:

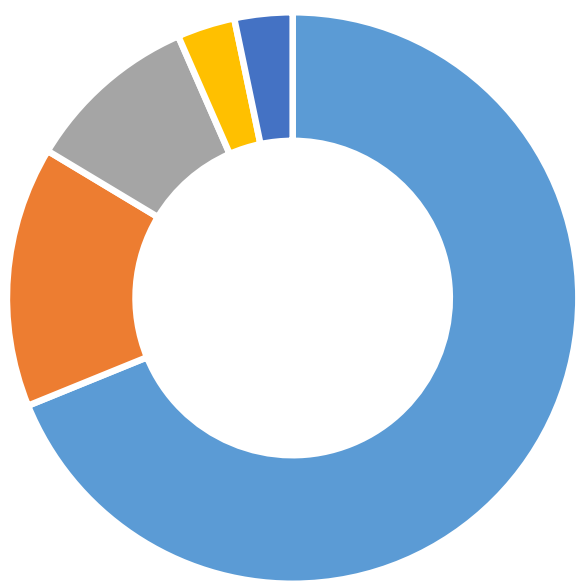

Of all three below mentioned $(69 \%)$

Corporate $(15 \%)$

Social (10\%)

Financial (3\%)

Performing of obligations (3\%)

Figure 5. Structural indicators of answers to questions that determine the most commonly used practices of practitioners (SMEs) about the image of the country

mentary decency and trust in financial and economic relations between the business entities. Among the variants proposed by the respondents, the financial responsibility and responsibility for fulfillment of obligations also appeared.

The main structural modules were: the guarantees of the decent attitude to the hired employees (27\%). The main principles of work with the counteragents (18\%), The standards of corporate conduct (16\%). The attitudes towards the environment and use of natural resources (12\%). The principles of interbranch and national partnership (10\%). The interactions with the financial institutions and the civil ones are less important.

The survey considers alternative ways of regulating the relations between the actors: between the state and business, between the financial institutions (banks, ICI, others) and business, and directly between the business representatives. In the first plane of relations, according to the respondents, the agreed legislative regulation of relations, including the Tax Code (73\%), is de- 
7. Choose/complete the key, in your opinion, structured models of the Code of Conduct for the conduct of SMEs:

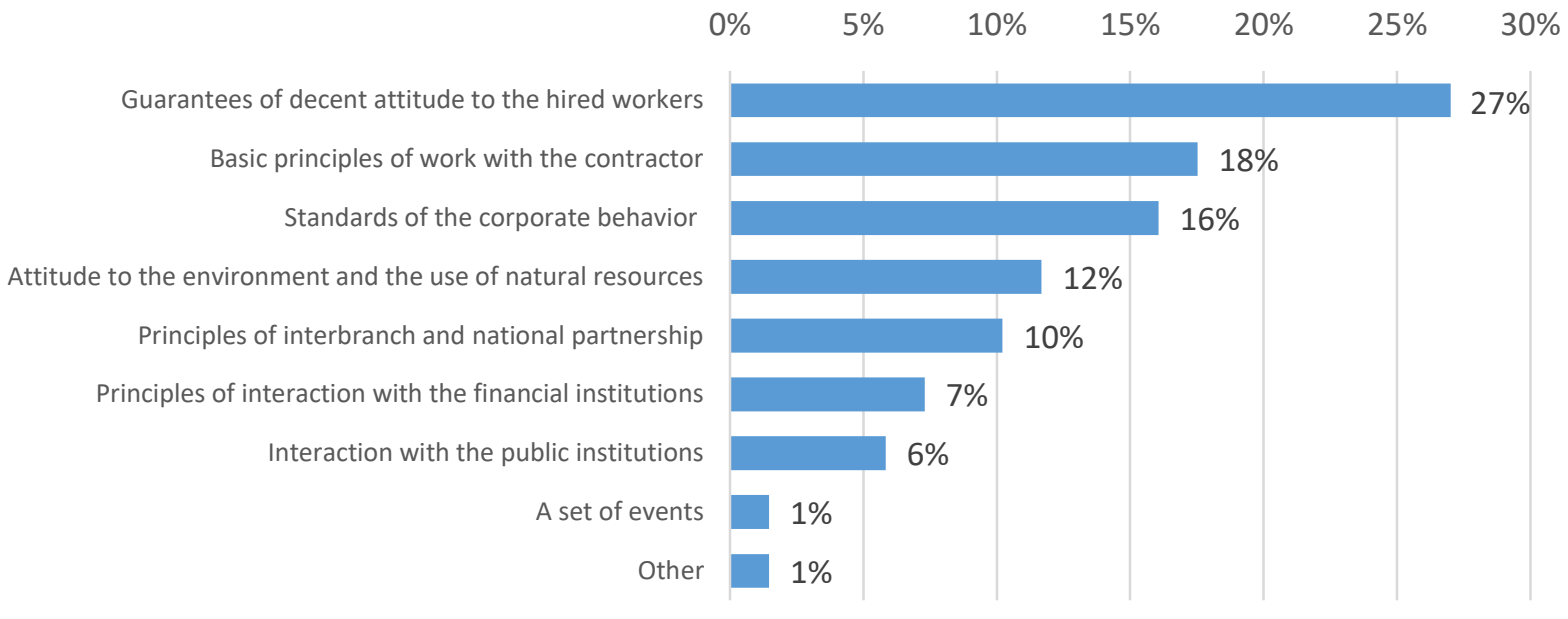

8. Maximum result in the regulation of relations can be achieved:

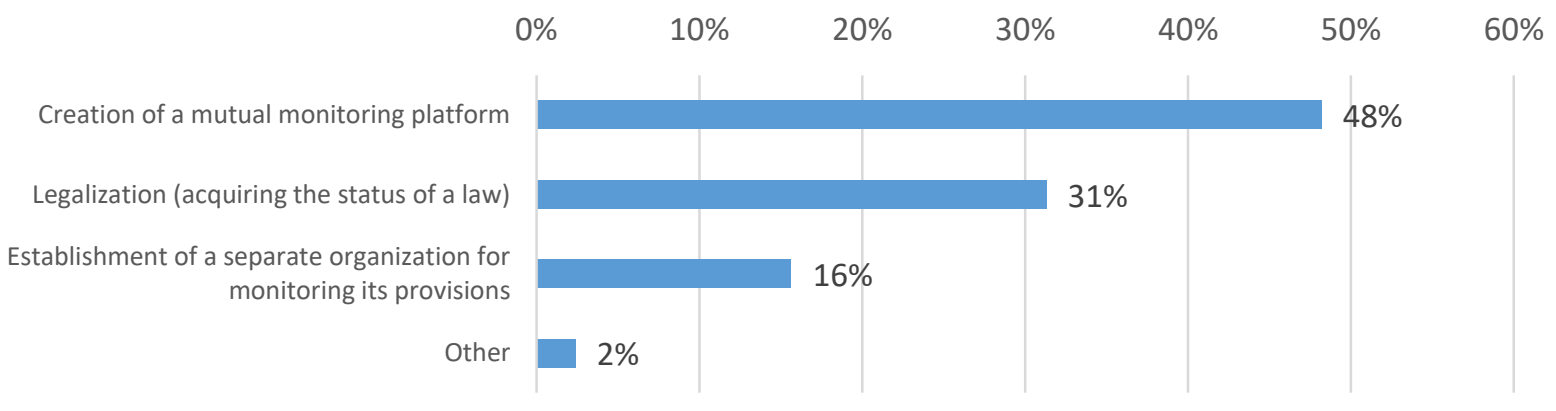

Figure 6. Structural indicators of answers to questions that determine the relevance and significance of the Code modules, $\%$

cisive. In the analysis of the second and third plane, the lack of a definite position of the society resulted in an equal number of votes for each of the proposed options. Thus, in the relationship between the financial institutions and business, supply and demand, law enforcement agencies, the court, internal treaties, legislation, and trust are important. In the relationship between the business representatives are legislation, market, customs, mutual interest, contracts, trust. It is possible to establish the necessity of harmonization and follow-up of mutual interests for the purpose of qualitative fulfillment of obligations by all parties of the economic and financial relations.

So, according to the survey results, $84 \%$ of the respondents can be considered as the optimists of the Code, who support the introduction of a single Code of Ethics for doing business, positively assessing its impact on other business components, for example, on the country's image or the investment attractiveness. Less than $16 \%$ of the respondents are categorical Code pessimists. At the same time, the low penetration of the corporate Codes of Ethics creates the demand for a single Code of Ethics for small and medium-sized businesses for the sector. The proposed structure of the Code is positively accepted by the respondents and is supplemented by some directions. The conducted research proves that the implementation of the Code of Ethics for conducting SMEs can significantly affect the investment attractiveness of this area in terms of compliance with its provisions by the SMEs. 
9. What, from your point of view, can be an alternative to the Code in the regulation of financial relations:

1) between the state and business:

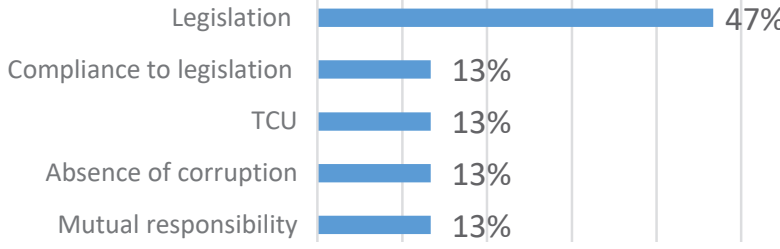

2) between financial institutions and business

Demand / proposition

Law enforcement agencies, court

Agreements

Legislation

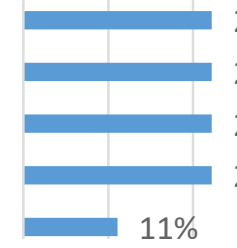

$22 \%$

$22 \%$

$22 \%$

$22 \%$

$$
\text { Trust }
$$

$11 \%$

3) between the business representatives

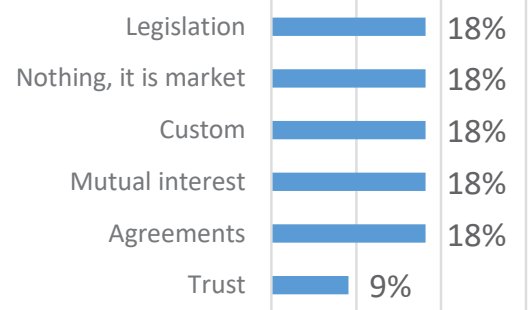

Source: Calculated by the authors based on the conducted research.

10. What are your suggestions for the content of the Code of Ethics for small and medium-sized enterprises?

Add to the Code provisions

on money transfers to and

from the country ( $2 \%)$

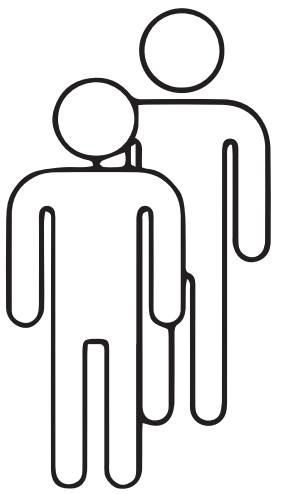

Figure 7. Structural indicators of answers to questions that determine the optimistic and pessimistic expectations and alternatives of the respondents, \%

\section{CONCLUSION}

Thus, many areas of the Code regulation require significant information support and explanatory work aimed at informing the business owners and decision-makers about the benefits of complying with certain rules and the effect of possible investment in these areas.

An overview of scientific and practical literature proves that the essential factors of doing business are not only economic, but also subjective (mental) peculiarities of the economic entities. And the study shows that the Ukrainian small and medium-sized enterprises are ready to work not only on their own image, but also on the image of the country, provided they have a comprehensive and all-inclusive approach to these SMEs. The survey and questionnaires of the representatives of the Ukrainian SMEs confirmed the need for the development and implementation of the provisions of the Code of Ethics for business, as well as the availability of potential demand for it. The respondents recognize the importance of adhering to certain international ethical rules in conducting business, which may encourage investment in Ukraine, but this is not the only factor affecting the investment attractiveness of the domestic business. Therefore, increasing the business climate is a complex issue, and the Code of Ethics in this context creates the opportunity to direct and encourage the participants to influence actively the environment: to recognize zero tolerance for corruption, to form and to maintain a clear position on interaction with the authorities.

Today, only two directions of the SMEs development are possible on the basis of the corporate, social and environmental responsibility. The first is the undoubted awareness and acceptance of the fact that 
business is responsible not only to its owners, but also to society as a whole. The second is the awareness of the SMEs of their own interest in reporting on actions within the corporate, social and environmental responsibility, that is, work on their own image (the consumer confidence, the partner confidence, the sustainable development of the country). The social responsibility of business depends directly on its growth and capitalization. For the SME, which is oriented towards a limited market and, as a rule, have limited financial resources, barteries are apparent and effective, in particular from the government. And if we are talking about the objectivity of doing business obligations to society, including on the part of environmental issues, then, the successful proposal is to facilitate the access to attracting the financial and credit instruments to finance their activities, identified as promoting innovation, product or process of production, and also reflects the social and environmental self-awareness of SMEs.

It is important that the Code of Ethics for the SMEs includes not only the corporate, social and environmental responsibilities, but also the financial one and the responsibility obligations for the counterparties, which are quite painful for today's SMEs' representatives. Compliance with the Code of Ethics of the SME will not only improve the business environment within the country, but will also contribute to the growth of the investment attractiveness of the economy as a whole and its economic entities in particular. As a result, it will have additional positive effects for the business in terms of increasing their profits in the medium to long term. Ukraine as a country with a high level of shadowing of the economic relations, uneven distribution of tax burden between the economic entities and the population, low level of the investment attractiveness for foreign and domestic investors is no exception. But business, both small and large, requires a change in the approaches to its organization, which is possible as a result of the introduction of the certain ethical rules and norms of conduct in the practice of the economic activity.

\section{REFERENCES}

1. Antoniuk, L., Gernego, Iu., Dyba, V., Polishchuk, Ye., \& Sybirianska, Yu. (2017). Barriers and opportunities for hi-tech innovative small and medium enterprises development in the 4 th industrial revolution era. Problems and Perspectives in Management, 15(4), 100-113. https://doi.org/10.21511/ ppm.15(4).2017.09

2. Center for "Corporate Social Responsibility Development" (n.d.). Retrieved from http://csr-ukraine. org/en/

3. EU-UA Civil Society Platform (n.d.). Retrieved from http://eu-uacsp.org.ua/en/contacts/

4. Grunig, J. E., \& Hunt, T. (1984). Managing public relations. New York, NY: Hilt, Rinehart and Winston.

5. Informational internet-platform for SMEs' innovations supports (n.d.). Retrieved from https://sme-sci.com

6. International Forum "Innovation Market” (IFIM) (n.d.). Retrieved from http://innovationmarket. com.ua
7. Kim Soo-Yeon, \& Ki Eyun-Jung (2014). An Exploratory Study of Ethics Codes of Professional Public Relations Associations: Proposing Modified Universal Codes of Ethics in Public Relations. Journal of Mass Media Ethics, 29, 238-257. https://doi.org/10.1080/08900523. 2014.946602

8. Longenecker, J. G., Moore, C. W., Petty, J. W., Palich, L. E., McKinney, J. A. (2016). Ethical attitudes in small businesses and large corporations: Theory and empirical findings from a tracking study spanning three decades. Journal of Small Business Management, 44(2), 167-183.

9. McKinney, J. A, Emerson, T. L., Neubert, M. J. (2010). The effects of ethical codes on ethical perceptions of actions toward stakeholders. Journal of Business Ethics, 97, 505-516. https://doi.org/10.1007/ s10551-010-0521-2

10. National baseline report "Sustainable Development Goals: Ukraine" (2017). Retrieved from http:// www.un.org.ua/ua/tsili-rozvytku- tysiacholittia/tsili-stalohorozvytku

11. Non-profit Public Organization "Economists Club" (n.d.). Retrieved from http://www. economists.org.ua

12. Paunov, C. (2016). Corruption's asymmetric impacts on firm innovation. Journal of Development Economics, 118, 216-231.

13. Pieczka, M., L’Etang, J. (2001). Public relations and the question of professionalism. In R. Heath (Ed.), Handbook of public relations (pp. 223-235). Thousand Oaks, CA: Sage. http://dx.doi. org/10.4135/9781452220727.n16

14. Schwartz, M. S. (2001). The nature of the relationship between corporate codes of ethics and behavior. Journal of Business Ethics, 32, 247-262.

15. Schwartz, M. S. (2005). Universal moral values for corporate codes of ethics. Journal of Business Ethics, 59(1-2), 27-44. https://doi.org/10.1007/s10551005-3403-2 
16. Selçuk, U., Spence, L., Simpson, R., 19. Tilley, E. (2015). The ethics \& Karakas, F. (2017). Work ethic, religion and moral energy: the case of Turkish SME owner-managers. The International Journal of Human Resource Management, 4(28), 1212-1235. https://doi.org/1 $0.1080 / 09585192.2016 .1166790$

17. Sharma, T., \& Dudeja, M. (2013). Business ethics in SMEs: an empirical study of selected units of Haryana. International Journal of Indian Culture and Business Management, 7(3), 307-323.

18. The Union of Enterepreneurs of Small, Middle-Sized and Privatized Enterprises (n.d.). http:// www.spmsppu.kiev.ua pyramid: Making ethics unavoidable in the public relations process. Journal of Mass Media Ethics, 20(4), 305320. https://doi.org/10.1207/ s15327728jmme2004_6

20. Vyakarnam, R., Bailey, A., Myers, A., \& Burnett, D. (1997). Towards an understanding of ethical behavior in small firms. Journal of Business Ethics, 16, 1625-1636. https:// doi.org/10.1023/A:1022452502299

21. Wiley, C. (2000). Ethical standards for human resource management professionals: A comparative analysis of five major codes. Journal of Business Ethics, 25(2), 93-114. https://doi. org/10.1023/A:1006230214847

22. World Economic Forum The Global Competitiveness Report (2017-2018) (n.d.). Retrieved from https://www.weforum.org/ reports/the-global-competitiveness-report-2s017-2018

23. Xu, G., \& Yano, G. (2017). How does anti-corruption affect corporate innovation? Evidence from recent anti-corruption efforts in China. Journal of Comparative Economics, 45(3), 498-519. http://dx.doi.org/10.1016/j. jce.2016.10.001 